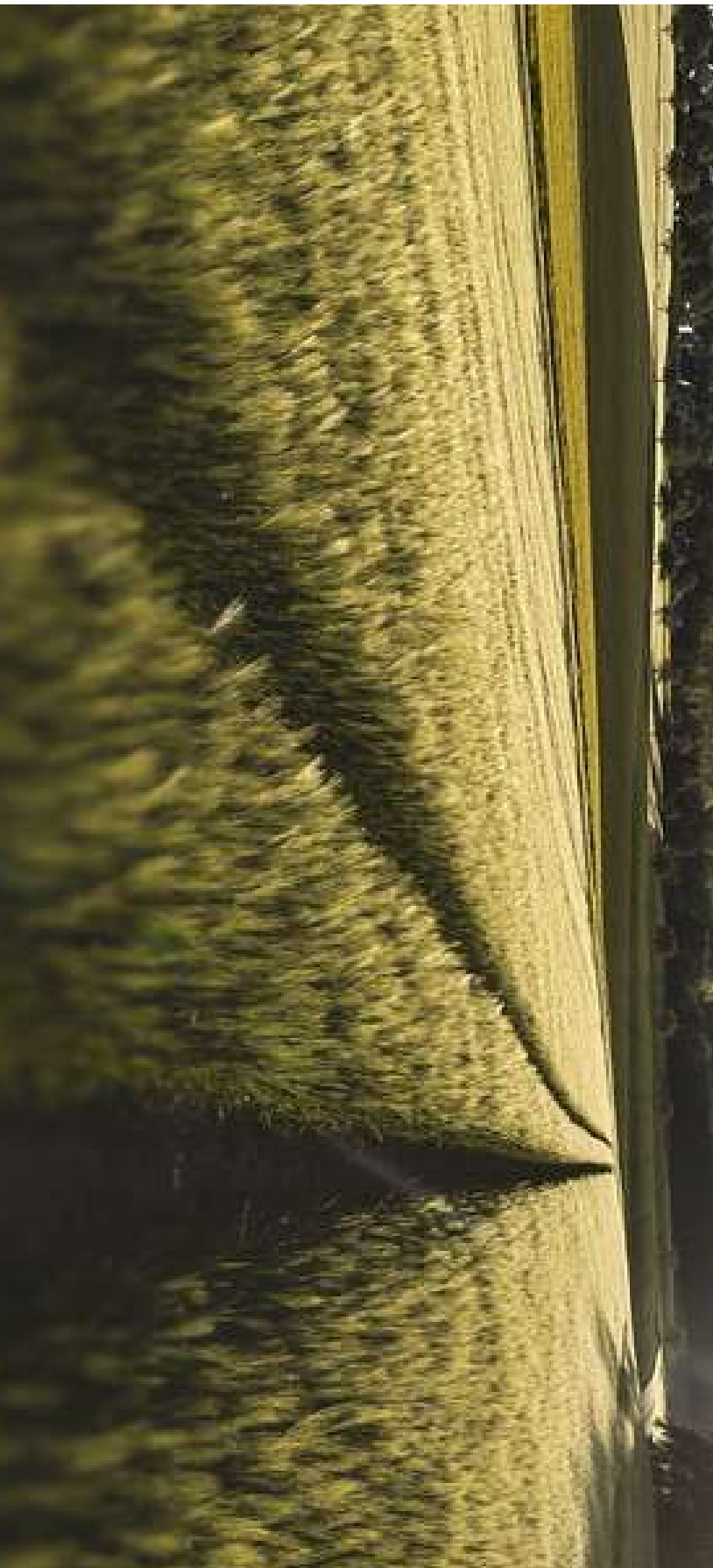


Estudo de recepção; Estudos Culturais; Agricultura familiar; Rural; Observação etnográfica. 


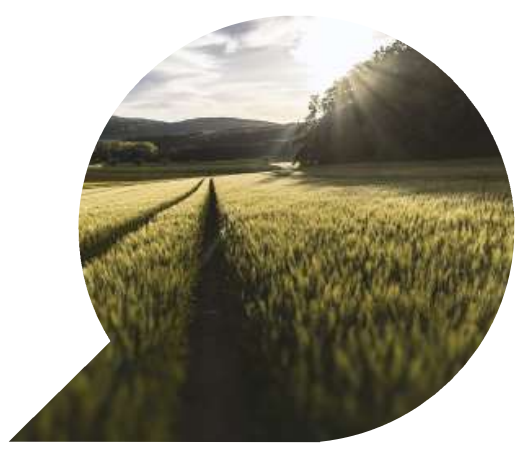

\section{Cotidiano e Recepção no Meio Rural: Um Estudo Etnográfico entre Agriculto- res Familiares Goianos}

\section{Cotidiano y Recepción en el Medio Rural: Un Estudio Etno- gráfico entre Agricultores Familiares de Goiás}

\section{Daily and Reception in the Rural Environment: An Ethno- graphic Study among Farmers from Goiás}

\section{GILMARA ROBERTO MOREIRA ${ }^{1}$}

\section{NÉLIA RODRIGUES DEL BIANCO²}

Resumo: O presente artigo apresenta pesquisa sobre o cotidiano e a recepção de mídia entre agricultores familiares do município de Itapuranga (GO). Com o objetivo de compreender a realidade do campo e sua relação com a mídia, a pesquisa lança mão da observação etnográfica e se estrutura a partir dos Estudos Culturais e dos estudos de recepção. O trabalho caracteriza a vida rural a partir dos seguintes elementos: roça, cotidiano, família, condições de vida e de sua relação com a mídia e o exercício da cidadania Por meio da imersão, foi pos-

\footnotetext{
1 Jornalista graduada pela UFG, com especialização em Comunicação Estratégica pela PUC-GO, mestranda em Comunicação pelo PPGCom da FIC/UFG. E-mail: gilmararobertom2@gmail.com 2 Doutora em Comunicação pela ECA-USP com estágio de pós-doutorado em Comunicação pela Universidad de Sevilla. Professora colaboradora do PPGCom da FIC/UFG e do PPPGCom da FAC/UNB . E-mail: nbianco@uol.com.br
} 
sível verificar, entre outros elementos: o papel do trabalho e da comercialização de alimentos como elementos determinantes do cotidiano; a função assumida por cada membros da família rural; e a maneira como o agricultor familiar incorpora a mídia em seu cotidiano - revelando a forma como se dá a negociação de sentido.

Palavras-chave: Estudo de recepção; Estudos Culturais; Agricultura familiar; Rural; Observação etnográfica.

Resumen: El presente artículo presenta una investigación sobre el cotidiano y la recepción de medios entre agricultores del municipio de Itapuranga (GO). Con el objetivo de comprender la realidad del campo y su relación con los medios, la investigación el estudio lanza mano de la observación etnográfica y se estructura a partir de los Estudios Culturales y de los estudios de recepción. El estudio caracteriza la vida rural a partir de los siguientes elementos: trabajo en el campo, cotidiano, familia, condiciones de vida y de su relación con los medios y el ejercicio de la ciudad. Fue posible verificar, entre otros elementos: el papel del trabajo y de la comercialización de alimentos como elementos determinantes del cotidiano; la función asumida por cada miembro de la familia; y la manera como el agricultor familiar incorpora a los medios en su cotidiano - revelando la forma como se da la negociación de sentido.

Palabras clave: Estudio de recepción; Estudios Culturales; Agricultura familiar; rural; Observación etnográfica.

Abstract: This article presents research on daily life and media reception among family farmers in the municipality of Itapuranga (GO). With the objective of understanding the reality of the field and its relation with the media, the research uses ethnographic observation and is structured from the Cultural Studies and the reception studies. The work characterizes the rural life from countryside, daily life, family, living conditions and its relationship with the media and the exercise of citizenship. Through immersion, it was possible to verify, among other elements: the role of work and the commercialization of food as determinants of everyday life; the role assumed by each member of the rural family; and the way the family farmer incorporates the media into his daily life - revealing how the negotiation of meaning takes place.

Keywords: Reception study; Cultural Studies; Family farming; Rural; Ethnographic observation. 


\section{Introdução}

A fim de desenvolver um estudo entre um grupo social que, historicamente, sofre um atraso no acesso a direitos civis, políticos e sociais básicos e também às ferramentas de informação e comunicação, a presente pesquisa teve como objetivo estudar o cotidiano e a recepção de mídia entre agricultores familiares goianos, especificamente do município de Itapuranga (GO). O município é o mais importante do Estado em termos de produção da agricultura familiar, apresentando um percentual de 19\% da população vivendo na zona rural, enquanto que a média nacional é de 15\% (IBGE, 2010) - e, por isso, foi o selecionado como espaço da pesquisa.

Ao buscar contribuir para a compreensão do cotidiano rural por meio da relação que agricultores familiares estabelecem com a mídia, espera-se que o estudo possa participar de um avanço científico a respeito de como se configura a vida no campo, ajudando a superar, na medida que lhe couber, a visão de atraso e subdesenvolvimento com que muitos ainda enxergam os agricultores brasileiros.

Consideradas peças fundadoras dos Estudos Culturais, obras de Richard Hoggart (1973), Raymond Williams (1958) e E. P. Thompson (1963) forneceram elementos teóricos para as primeiras reflexões propostas. Autores como Stuart Hall (2003) e Nestor García Canclini (2015) foram elementares para a compreensão dos Estudos Culturais na América Latina. Jesús Martín-Barbero (2015) com seu aporte teórico ofereceu subsídios para o debate das mediações que se dão por meio da recepção de mídia. Estudos de Maria Immacolata Vassalo de Lopes (1993; 1999; 2014a; 2014b) e Nilda Jacks $(2006 ; 2008)$ ofereceram a base para a análise dos processos de recepção no contexto brasileiro.

Com base na observação etnográfica, considerada como estratégia metodológica capaz de lançar luz sobre as práticas de sociabilidade e recepção (LOPES, 2018a), o estudo elegeu a roça, o cotidiano, a família, as condições de vida e a relação do agricultor familiar com a mídia e o exercício da cidadania como elementos capazes de realizar a caracterização etnográfica.

\section{Referencial Teórico}

O presente estudo lançou mão de abordagens desenvolvidas pelos Estudos Culturais Britânicos para explicar as relações estabelecidas entre a mídia e a sociedade. Ao posicionar a cultura como um elemento vivo cons- 
truído a partir das redes de relacionamentos estabelecidos no cotidiano e, principalmente, ao inaugurar um olhar para as culturas populares construídas pelos menos favorecidos, tal abordagem constitui a base teórico-metodológica que permite olhar para o universo rural em busca de seus elementos fundantes.

O escopo que veio a constituir a gênese desse campo de estudo tem como instituição fundadora o Centro de Estudos Culturais Contemporâneos (na sigla em inglês, CCCS) da Universidade de Birmingham, na Inglaterra. Os estudos de Hoggart (1973) recaem predominantemente sobre materiais culturais dos meios de comunicação e da cultura de massa por meio de abordagens qualitativas. Por meio de uma contextualização da cultura da classe trabalhadora, o trabalho "inaugura o olhar de que no âmbito popular não existe apenas submissão, mas também resistência" (ESCOSTEGUY, 1998, p. 88-89). Na obra de Williams (1958), os avanços encontram-se principalmente no desenvolvimento dos debates que avaliam o impacto dos meios de massa na cultura. Por sua vez, Thompson (1963) reconstrói parte da história da Inglaterra numa perspectiva social, do ponto de vista dos menos favorecidos. O pesquisador também tem a compreensão da cultura, não como um modo de vida global, mas como uma rede de relacionamentos e práticas que fundam a vida cotidiana (ESCOSTEGUY, 1998).

No que ser refere aos Estudos Culturais na América Latina, uma das principais contribuições está no desenvolvimento do conceito de culturas híbridas, promovido pelo antropólogo argentino Néstor García Canclini. Nascida do cruzamento de manifestações que não se inserem nem no culto, nem no popular, considera-se que a hibridização cultural precisa ser avaliada por outras dimensões que não exclusivamente as categorias dicotômicas utilizadas quando convencionalmente se fala do popular (tradicional e moderno ou subalterno e hegemônico) (CANCLINI, 2015).

Canclini (2015) considera ainda que a vida urbana não significa a dissolução do sujeito no anonimato, mas sim na formação de grupos populares fragmentados que não encontram na cidade um espaço de constituição de suas identidades. Para o autor, por vezes, os meios de comunicação são capazes de contribuir para superar a fragmentação cultural que se realiza nesse cenário. Nesse ponto, Canclini avalia que a mídia se transformou numa espécie de grande mediadora, substituindo outras interações coletivas.

A partir do desenvolvimento dos Estudos Culturais, o estudo das audiências foi liberto da visão do modelo reducionista dos efeitos, compreendendo a recepção como uma "prática complexa de construção social de 
sentido" (LOPES, 2018, p. 2). Foi só então que as audiências, por sua vez, passam a ser consideradas como formadoras de uma complexa estrutura em que cada grupo social possui sua própria identidade e seu próprio código, determinado pelas tradições culturais de seu grupo.

Além disso, (1) a concepção da comunicação como um processo de recepção e resposta, e não apenas de transmissão, conforme indicou Raymond Williams na obra Culture and Society; (2) a concepção de um receptor que pode aceitar ou negar o que é proposto pela mídia; e (3) a abordagem do sujeito a partir de seu perfil étnico, sexual e de consumo contribuem para o desenvolvimento dos estudos de recepção na América Latina (COSTA; RODRIGUES, 2014).

Os estudos das mediações foram, de maneira mais profunda, levados a cabo pelo antropólogo e filósofo colombiano, Jesús Martín-Barbero (2015). Para o autor, "o campo daquilo que denominamos mediações é constituído pelos diversos dispositivos através dos quais a hegemonia transforma por dentro o sentido do trabalho e da vida da comunidade" (MARTÍN-BARBERO, 2015, p. 265).

No clássico livro Dos Meios às Mediações, Jesús Martin-Barbero (2015) abre discussão acerca do papel da comunicação na formação de novos modelos de sociedade e na inserção da cultura como um fator de mercado. Nesse sentido, o autor destaca que "a comunicação e a constituem hoje um campo primordial de batalha política” (2015, p. 13).

Situada entre os maiores pesquisadores dos estudos de recepção no Brasil e na América Latina, Maria Immacolata Vassalo de Lopes define a recepção como um processo cultural e político, que não pode ser reduzido ao psicológico e ao cotidiano (LOPES, 1993). Para a autora,

Os estudos culturais permitem uma problematização mais elaborada da recepção em que as características socioculturais dos usuários são integradas na análise não mais de uma difusão, mas de uma circulação de mensagens no seio de uma dinâmica cultural. O polo da reflexão é progressivamente deslocado dos próprios meios para os grupos sociais que estão integrados em práticas sociais e culturais mais amplas (...). A descrição detalhada deste percurso dá à análise da recepção o caráter de uma etnografia das audiências. (LOPES, 2018, p. 2).

Os processos de recepção devem ser vistos como parte integrante das práticas culturais que articulam processos tanto subjetivos como objetivos, tanto micros (ambiente imediato controlado pelo sujeito) como macros (es- 
trutura social que escapa a esse controle). A recepção é então um contexto complexo e contraditório, multidimensional em que as pessoas vivem o seu cotidiano. Ao mesmo tempo, ao viverem esse cotidiano, as pessoas se inscrevem em relações de poder estruturais e históricas, as quais extrapolam as suas práticas (LOPES, 1993, p. 85).

Importante destacar que os estudos de recepção contribuem ainda para uma realocação do conceito de audiência. Lopes, Borelli e Resende (2002) definem audiência como um conjunto de pessoas quem contato com uma mensagem, em que o interesse recai sobre os níveis de duração da exposição, probabilidade de percepção, condições de contato, colhidos por instrumentos de medida tomados da psicologia experimental e social (LOPES, BORELLI E RESENDE, 2002, p. 28).

\section{Abordagem metodológica}

Considerada como um tipo de pesquisa associada ao desenvolvimento de conhecimento sobre a cultura com base nas estruturas de significados (GEERTZ, 1989), o estudo se sustenta buscou executar uma observação nos moldes da etnografia. Tida como um ramo da antropologia, a etnografia tem como objetivo compreender a cultura material e imaterial de um grupo por meio da observação, da descrição, da análise e da reconstituição das culturas (MARCONI; PRESOTTO, 1986).

A escolha se justifica pela vivência de campo proporcionada por um estudo, que torna possível compreender de maneira mais integrada a maneira como se organiza a família rural e de como se dá a recepção, a partir de um olhar menos funcionalista.

Diante do exposto, espera-se que a metodologia selecionada para compor o estudo de recepção seja capaz de realizar uma "reconstrução empírica" do cotidiano da agricultura familiar (LOPES, 2018a, p. 23). Para tanto foram utilizadas como ferramentas de pesquisa a observação etnográfica, que permitirá a observação das práticas de sociabilidade e recepção, e as entrevistas, que darão conta da dimensão subjetiva da recepção (LOPES, 2018a).

A fim de cumprir tais objetivos o estudo foi operacionalizado por meio de visita de imersão no cotidiano de uma família selecionada, utilizando-se de anotações, registros fotográficos, gravações de áudio e conversas informais ${ }^{3}$.

3 Para realização do estudo, a pesquisa teve aprovação do Comitê de Ética em Pesquisa da UFG, conforme parecer de número 2.707.866, de 2018. 


\section{Objeto de estudo}

Para a seleção dos produtores do município para compor o recorte da pesquisa foram consideradas famílias que recebem atendimento da Agência Goiana de Assistência Técnica, Extensão Rural e Pesquisa Agropecuária (Emater). A delimitação de produtores ${ }^{4}$ por sua relação com a Emater se justifica pelo fato de a Agência ser a única instituição responsável por promover o serviço de assistência técnica e extensão rural (Ater) pública no Estado de Goiás, especialmente entre agricultores familiares e os de menor renda.

Inicialmente, as visitas exploratórias levaram ao contato com nove famílias. Os encontros foram realizados com base na seleção por conveniência, uma vez que todos eles foram realizados durante ações de trabalho promovidas pela Emater. Entre elas, a família de Moisés Nogueira da Silva (65) e Divina Rosa da Silva (59) foi a selecionada para o estudo.

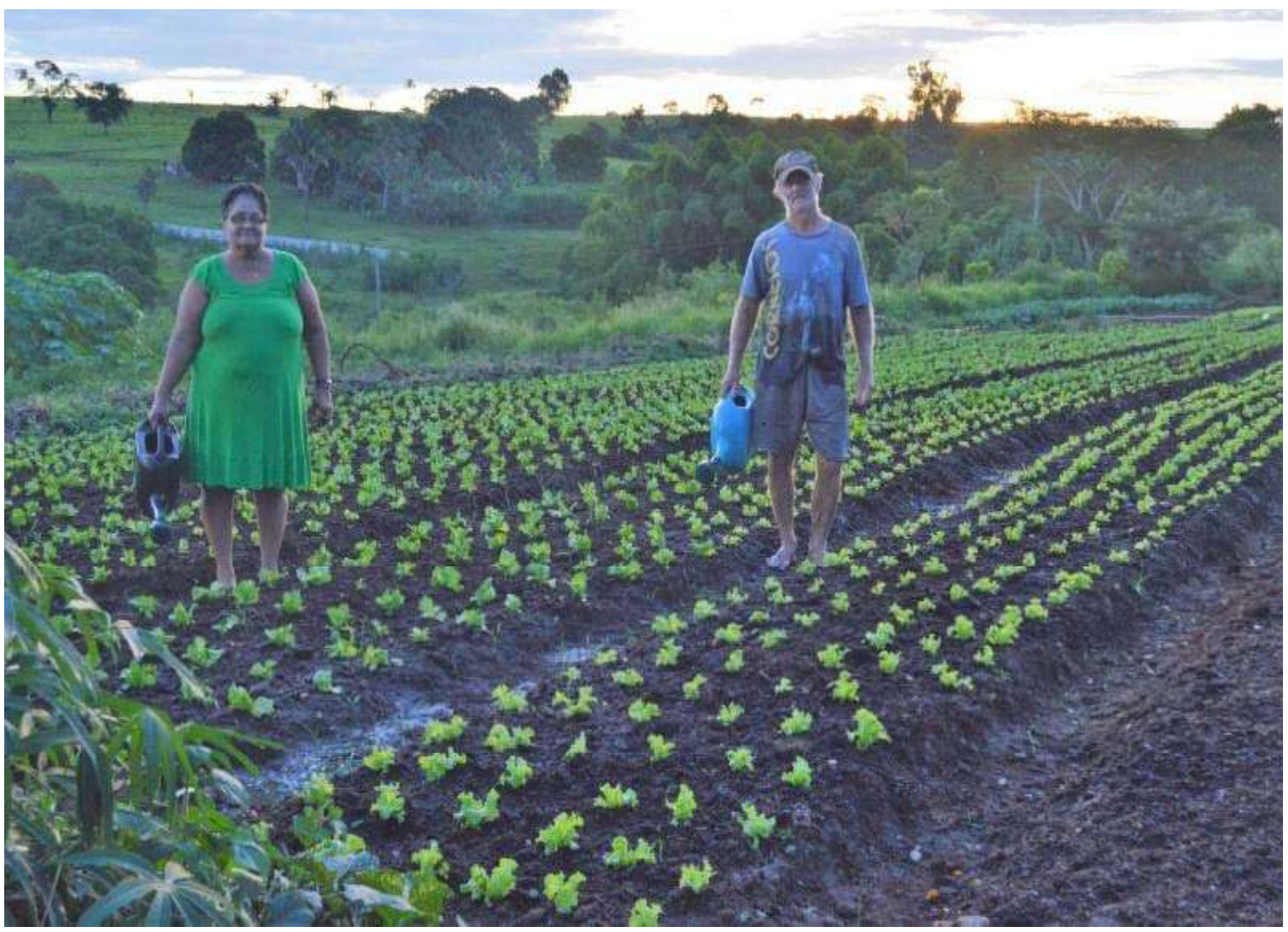

Figura 01: Moisés e Divina

Autoria e fonte: a autora

4 Importante destacar também que a autora do presente estudo ocupa cargo de servidora pública comissionada na entidade em questão. 
O casal vive na Chácara São Sebastião do Xixá, localizada nos limites da cidade. Embora tenha todas as características de um imóvel rural e não haja imóveis residenciais à sua volta, a propriedade é tida como urbana. Formada pelo que corresponderia a 44 lotes, a família é tributada por todas essas áreas, chegando a pagar anualmente cerca de $\mathrm{R} \$ 5$ mil de impostos, enquanto que imóveis rurais deste mesmo tamanho chegam a ser tributados em apenas $\mathrm{R} \$ 20$.

A principal receita da família é originária da produção e comercialização de hortaliças. Sazonalmente, a venda de frutas que crescem num pomar doméstico complementa a renda. Moisés cuida sozinho da horta em que são produzidos principalmente vegetais folhosos, como alface e couve. Divina, que ajudava na horta e na venda de hortaliças em diferentes pontos da cidade, tem sofrido de problemas no joelho que tem limitado sua participação nas atividades produtivas.

\section{Caracterização Etnográfica}

A partir da observação realizada na família de Moisés e Divina, foi realizada uma caracterização etnográfica do agricultor familiar de Itapuranga. Considerando que a etnografia "requer alguma generalização e comparação, implícita ou explícita" (MARCONI; PRESOTTO, 1986, p. 32) por ser um estudo descritivo, optou-se por produzir um texto com linguagem generalizada que integra dados coletados.

Para fins de organização, o estudo propõe o registro dos dados da pesquisa com base nas seguintes categorias:

A) A roça: envolve a caracterização de elementos estruturais da casa e da lavoura. Busca mostrar como é a condição de vida no campo das famílias, evidenciando como o lugar em que vivem estabelece relação com a maneira como agem e se organizam.

B) O cotidiano: integra o comportamento de rotina das famílias, buscando esclarecer como as práticas cotidianas se relacionam com a organização da vida no campo e com a recepção de mídia.

C) A família: especifica a maneira como se posiciona cada um dos membros da família, evidenciando seus lugares de poder e subordinação, seja quanto ao que se trata dos aspectos cotidianos, seja relacionando-os com a recepção de mídia.

D) As condições de vida: apresenta elementos da vida no campo, bus- 
cando evidenciar em que ela se aproxima e se distancia da vida de quem mora na cidade.

E) A relação com a mídia e com o exercício da cidadania: apresenta os lugares ocupados pela mídia no cotidiano dos agricultores (sejam eles em seus aspectos físicos ou intangíveis), relacionando-os com os elementos da propriedade, do cotidiano e da família, analisados anteriormente. Discute ainda a maneira como o acesso a produtos de comunicação se relacionam com o exercício da cidadania pelo agricultor familiar.

\section{A Roça}

A relação do agricultor familiar ${ }^{5}$ com a terra é o que, predominantemente, o diferencia das outras classes da sociedade. Essa relação não trata apenas do lugar no espaço que ocupa, mas sim do significado que lhe atribui. Para o agricultor familiar, terra não é sinônimo de sujeira, poeira ou de um chão sobre o qual se constroem edificações e estradas. Para ele, a terra é de onde vem o alimento que viabiliza o sustento de toda a sociedade, e não apenas a vida de quem reside no campo.

A terra é, para o agricultor familiar, como uma entidade sagrada que precisa ser bem tratada para que continue a nutrir a vida. Esses cuidados constroem um significado diferente para a palavra sujeira, que para o agricultor familiar não representa mancha, acumulação de desejos, resíduo, poeira ou excremento. Para ele, sujeira é qualquer invasor da terra que prejudique a lavoura - mesmo que esse invasor seja um capim brachiária verde e vistoso. Uma lavoura com mato ou palha seca da capina é uma lavoura suja - o que é motivo de vergonha porque representa descuido com a terra.

A relação com a terra também determina a posição da casa dentro da propriedade. Construída em lugar quase sempre mais alto, de onde se pode ver toda propriedade, a casa está num lugar onde muitas vezes seria mais difícil plantar por causa do relevo. Comumente, quanto mais antiga a casa, mais conforto ela tem. Isso porque o imóvel é construído tendo apenas o básico para se viver nele. Depois, com o passar do tempo e as economias, vão se conquistando os alpendres, as lajes, entre outros elementos que deixam a casa mais confortável.

5 Ao utilizar o termo "o agricultor familiar" a pesquisa não se restringe a caracterizar o homem do campo, mas também as mulheres, crianças, jovens, adultos e idosos com suas diferentes identidades de gênero. A escolha do termo no masculino plural deve-se apenas a uma simplificação para fins de generalização. 
A casa é também o elemento que liga a roça à rua, termo que assume também significado diferente do que possui na cidade. Rua não representa um corredor plano, pavimentada ou cascalhada por onde transitam veículos. Para o agricultor familiar, rua é o lugar externo à roça, ou seja, a cidade e tudo que está do lado de fora do universo rural. As pessoas da rua, as coisas da rua, as atividades que se faz na rua envolvem uma série de elementos que contrastam com a vida rural. Viver na rua não significa não ter lugar onde morar, mas significa viver longe da roça, que para ele é o lugar do lar.

\section{O Cotidiano}

O dia a dia da família do agricultor familiar se organiza em torno de sua atividade produtiva, que normalmente não tem hora fixa para começar ou terminar. Depende do estágio da lavoura, do número de animais para ordenhar e também do sol - enquanto há luz do sol, o trabalho está presente.

Embora o trabalho no campo esteja à mercê da luz do sol, as atividades produtivas começam antes do amanhecer e terminam depois de escurecer. Nesse período, são realizadas tarefas complementares ao trabalho da lavoura, tais como a embalagem e preparação de alimentos para comercialização, preparo de ferramentas e adubos, entre outras atividades.

No dia a dia, as refeições representam marcos de virada da rotina da família. A hora de sair da cama é a hora do café. A hora do almoço é a hora de interromper a atividade no campo para restabelecer as forças para o trabalho. Entre as famílias em que há jovens e crianças em idade escolar, o almoço representa ainda o horário de retorno deles à casa e, consequentemente, à realização de tarefas que os envolvem, tais como a limpeza da casa e o cumprimento de atividades escolares. $O$ lanche da tarde (ou merenda) serve principalmente os mais jovens e a mulher da família, já que o homem não costuma interromper o trabalho no meio da tarde para comer. A hora do jantar, por sua vez, marca o início do período diário de descanso.

Para o agricultor, o trabalho depende do estágio em que se encontra a lavoura. Há épocas em que é preciso irrigar as culturas com o nascer do sol. Em outros tempos, a chuva se encarrega desse serviço. Atividades de adubação e revolvimento da terra são executadas normalmente pelo homem da família.

A etapa de venda dos alimentos também é parte importante da rotina do agricultor familiar. A comercialização é realizada em feiras, em pontos distribuídos pela cidade, para mercados, por atravessadores que levam os alimentos à Central de Abastecimento de Goiás (Ceasa), localizada em 
Goiânia (GO), e também por meio de entregas em domicílio ou por retiradas diretas na propriedade.

As feiras do município de Itapuranga são tidas como o principal ponto de comercialização de alimentos do agricultor familiar. Com hora certa para começar e acabar, a Feira do Produtor Rural é a atividade a qual se dedica todas as quintas-feiras. Toda a rotina do dia é organizada para que às $16 \mathrm{~h}$ - prazo máximo em que é permitido acessar a área da feira de carro para o transporte dos alimentos -, ele já esteja com a sua banca instalada.

Além dos centros organizados de comercialização, a rodoviária do município de Itapuranga é um local já reconhecido como um espaço de rotina de venda hortaliças e outros alimentos da agricultura familiar, mesmo que o comércio não seja regulamentado pela prefeitura municipal. Durante a semana, em horário comercial, diferentes agricultores familiares se dirigem até lá para vender seus produtos.

Embora sejam também pontos de venda, os mercados da cidade não são os melhores fregueses do agricultor familiar. Isso porque os estabelecimentos exigem periodicidade fixa de entrega e preços baixos, como os encontrados na Ceasa, condições que o agricultor familiar não consegue cumprir. Mesmo assim, em alguns casos, ele oferece o excedente da produção aos mercados e tem sucesso na venda.

\section{A Família}

$\mathrm{Na}$ família do agricultor familiar, homens, mulheres e jovens possuem papéis bem definidos, seja nos cuidados com a casa, seja nos cuidados com a roça. Responsável pela administração da casa e do dinheiro, a mulher assume o papel de gestora da família. É ela quem tem o controle das despesas de uma maneira mais abrangente. Em alguns casos, quando o homem cuidou do dinheiro em alguma época, a família costumava passar por um número mais frequente de situações de dificuldade financeira. Isso porque ele acabava investindo mais em insumos e equipamentos para a propriedade do que o orçamento da família comportava.

Considerado mais "sem cabeça" do que a mulher para cuidar das finanças, o homem entrega o dinheiro que ganha à esposa e retira o necessário com ela sempre que preciso. Com conhecimento e domínio dos recursos necessários para as despesas domésticas, ela é quem sempre sabe quanto se pode investir na propriedade ou quanto gastar com itens supérfluos. É ela quem cuida de abastecer a despensa da casa para que nada falte. 


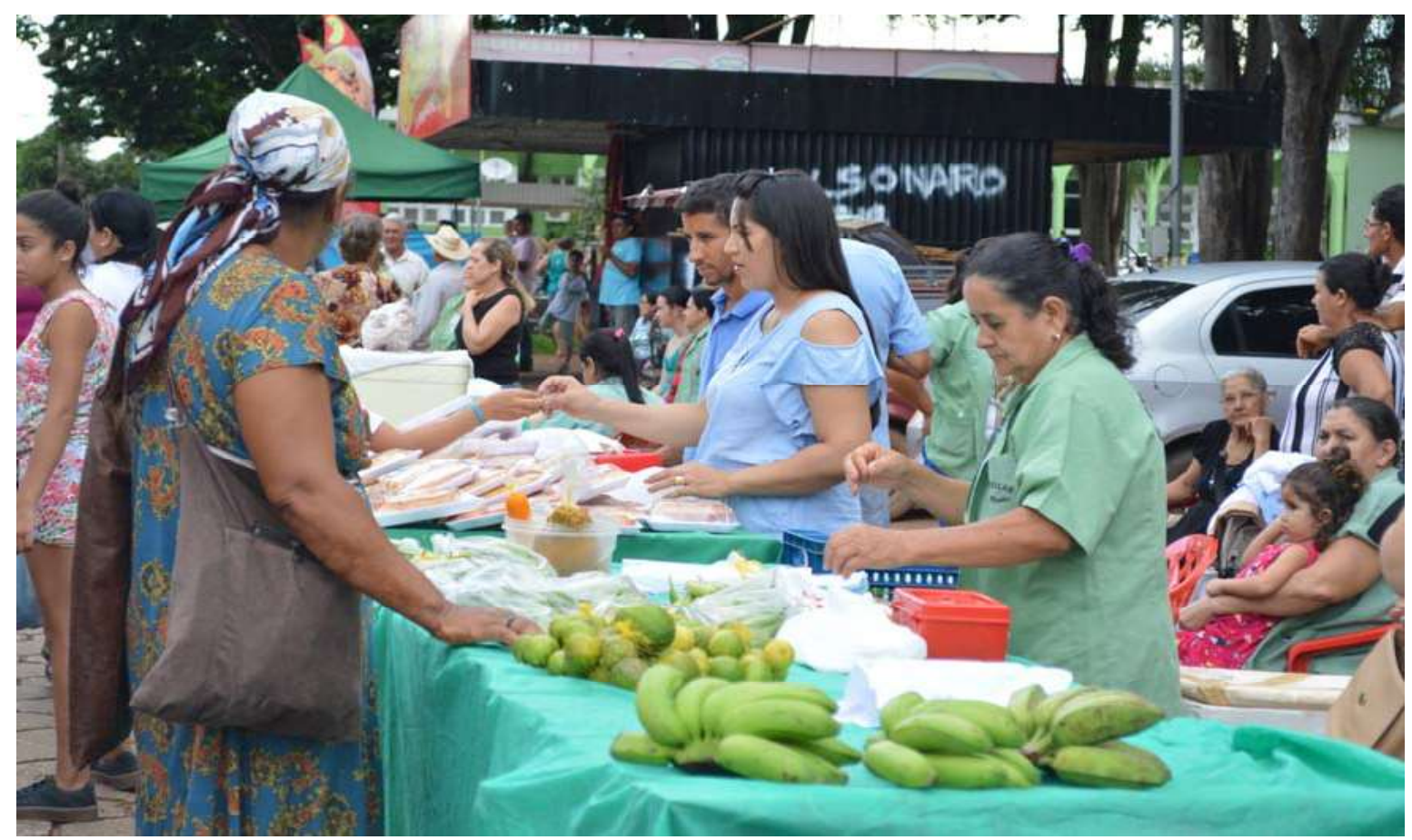

Figura 02: Feira do Agricultor Familiar

Autoria e fonte: a autora

Para além do que se relaciona com as finanças da família, a mulher é também a responsável para que todas as tarefas do dia a dia sejam cumpridas dentro do prazo. É ela quem acorda as crianças para a escola, quem lembra o marido do horário de sair para a feira ou para as reuniões da associação e a hora de cada um tomar banho na casa.

Mesmo que o controle financeiro e da rotina da casa estejam a cargo da mulher, é o homem quem assume o papel de provedor da família, pois é predominantemente o trabalho dele que gera os alimentos que sustentam a casa. Por mais que as tarefas na roça sejam compartilhadas, o trabalho pesado do dia a dia no campo é realizado pelo homem e é o que parece ter mais valor para a família.

Importante destacar que, mesmo que o papel de provedor ainda seja ocupado pelo homem, já se podem observar fatores que caracterizam uma organização mais igualitária da família rural. Prova disso é a constante valorização do trabalho feminino, tanto por parte do homem como por parte da mulher, que reconhece e faz questão de destacar o quanto suas atividades são importantes para a organização da família sejam eles trabalhos relacionados à lida na roça, a atividades domésticas ou a trabalhos extras que complementam a renda.

Porém, evidentemente, existem ainda distinções entre o trabalho do homem e da mulher. Muitas vezes, essas diferenças são justificadas pela 
capacidade de força física de ambos os sexos. Observa-se ainda que o trabalho da mulher é visto predominantemente como atividade de apoio, e não como uma atividade autônoma. A mulher assume a posição de quem serve e auxilia, e mesmo que a gestão financeira da casa esteja sob seu comando, ainda é o homem quem toma as decisões mais importantes da família.

Os jovens e crianças assumem papel de auxiliares na organização do lar. Dedicados principalmente aos afazeres domésticos, especialmente as meninas, eles pouco contribuem com as atividades produtivas. Em alguns casos, ajudam na venda de produtos na feira ou nas bancas da rodoviária da cidade, mas não ajudam nas atividades da roça.

A ausência da participação dos jovens nas atividades produtivas se deve especialmente ao desinteresse pela lida. $\mathrm{O}$ trabalho no campo não representa um atrativo para eles, que nos discursos e na postura, buscam passar por habitantes da cidade e não do campo. Outro motivo que afasta os jovens da atividade rural é a valorização dos estudos. $\mathrm{O}$ agricultor familiar entende que os filhos e netos só terão uma vida melhor se puderem se dedicar a uma carreira acadêmica e, por isso, não exigem participação deles na roça.

\section{As Condições de Vida}

Embora considere que a vida no campo é dura e que os filhos e netos mereçam ualgo melhor, o agricultor familiar se orgulha do que faz e não se imagina trabalhando com outra coisa. A dificuldade que ele enxerga não está relacionada ao trabalho desgastante, mas sim às condições externas à produção, tais como a tributação, a falta de apoio dos governos municipais, estaduais e federais, e mesmo a maneira pejorativa com que a sociedade urbana o enxerga.

O agricultor familiar tem conviçção de que é o seu trabalho que alimenta e sustenta toda a sociedade. Mas afirma isso sem arrogância. Ele fala com desconsolo e tristeza de uma sociedade que o olha como uma pessoa menor porque se veste de maneira humilde, tem pouco estudo e nem sempre sabe usar as palavras de maneira correta. Ele desconhece o motivo dessa soberania urbano sobre o rural, mas gostaria de compreender. Mesmo sendo visto como alguém que a sociedade urbana julga ser menor, o agricultor acha que a vida é difícil, mas é boa.

A geladeira do agricultor familiar é farta. As prateleiras cheias de ali- 
mentos muitas vezes contrastam com a simplicidade dos ambientes. As dificuldades de acesso a mercados, localizados na rua, fazem com que os estoques sejam sempre grandes para não se correr o risco de nada faltar. Em sua maioria, os alimentos não são de marcas de primeira linha, porque mesmo que disponha de dinheiro para adquirir produtos mais caros, o agricultor familiar é acostumado ao mais simples e se satisfaz com ele.

A simplicidade também dá o tom à maneira do agricultor familiar se vestir. Composto por peças básicas, o guarda-roupas dele tem roupas de trabalho e roupas de passeio. Nunca uma peça que pertence a um universo é usada noutro. Porque a roupa de trabalho é puída, furada e manchada. Já a roupa de passeio é muito limpa e conservada - embora nem sempre seja nova.

Essa diferenciação mostra que existe uma grande preocupação em parecer bem para o mundo fora da porteira. Para sair à rua, ele busca eliminar os resquícios que a terra deixa em si para que não seja julgado como alguém sujo ou mal apresentado. Já na roça, ele não se importa com julgamento. $\mathrm{O}$ trabalho justifica as condições de suas roupas e calçados e ali, enquanto ele trabalha, não se importa que seja visto assim.

Para além dos limites domésticos, o agricultor familiar sofre a dificuldade de acesso a direitos civis, políticos e sociais básicos. Ao acesso a aposentadoria rural é um bom exemplo. Para conseguir o benefício, o produtor precisa comprovar vínculo com a terra, seja por meio de escrituras de imóveis, seja por meio de contracheques ou registros em carteira de trabalho. No entanto, agricultores que não tiveram condições de escriturar os imóveis (outra dificuldade de acesso) ou mesmo trabalhadores rurais que sobrevivem do trabalho na roça, mas que não tem vínculos formais, nunca conseguem se aposentar.

Inúmeros outros exemplos podem ser citados na área de infraestrutura. $\mathrm{O}$ agricultor familiar vive anos sem luz elétrica depois de se estabelecer em sua propriedade. As estradas que dão acesso à suas terras são quase sempre esburacadas e mal cuidadas. Muitos dos benefícios que chegam são realizados com a contrapartida do agricultor, que busca viabilizar equipamentos e insumos para a realização de atividades como patrolamento e cascalhamento de estradas.

Embora não tenham acesso a muitos dos direitos básicos, o cumprimento de deveres é exigido do agricultor familiar. Mesmo que ele não receba orientação para uso correto da água e para o descarte de dejetos, ele é multado se faz despeja esgoto em lugar inapropriado. Mesmo sem nunca ter recebido orientação técnica que falasse da importância de se preservar 
a vegetação nativa à beira de uma nascente, ele é penalizado se arranca as árvores para seu gado pastar. Mesmo que considere injusta a abordagem realizada por órgãos de fiscalização, tais como o Ministério Público ou por agências de defesa, o agricultor familiar costuma compreender o erro do que fez. Ele não culpa a falta de orientação prévia, mas sim passa a se preocupar com o que é preciso fazer para continuar trabalhando dentro do que determina a lei.

Tais condutas indicam a autonomia do agricultor familiar frente às autoridades públicas. Acostumado a viver isolado e sem apoio, ele não espera que o poder público cuide da manutenção dos seus direitos - o que pode significar certa autonomia no exercício de sua cidadania.

\section{A Relação com a Mídia e com o Exercício da Cidadania}

A relação do agricultor familiar com a mídia se constrói a partir do seu cotidiano de trabalho. Para ele, a mídia é um instrumento fundamental que o mantém em contato com o mundo exterior à propriedade e onde também pode ver a sua realidade ser retratada para a sociedade urbana por meio dos programas rurais. Mas, assim como todas as outras atividades de seu cotidiano, o contato com a mídia está sujeito às oportunidades geradas entre uma atividade e outra de trabalho.

A inserção da recepção de mídia no cotidiano do agricultor familiar se modifica conforme o meio midiático a que se refere. Quando se tratam de produtos do rádio, observa-se que suas características de um meio pano de fundo o permitem ser acessados mesmo durante a rotina de trabalho do agricultor familiar. Ele se conecta às emissoras por meio de aparelhos elétricos ou a pilha e também pelo celular.

O rádio é, de longe, a mídia preferida pelo agricultor familiar de Itapuranga. Por ser uma mídia de baixo custo, de longo alcance e por suas características de pano de fundo, foi a mídia referenciada por todas as famílias entrevistadas. Além disso, sua característica de oralidade e o apreço da ferramenta pelos mais velhos fazem com esteja presente na em todos os lares rurais visitados.

Em Itapuranga, há três emissoras locais que podem ser acessadas pela internet ou por aplicativos de celular: a Rádio Mais FM, a Rádio Primavera FM e a Rádio Alternativa FM.

Embora também ouçam música e acompanhem outros programas das emissoras locais, os programas jornalísticos da manhã são os produtos de 
mídia mais acessados pelo agricultor familiar. Entre os conteúdos acessados, o de maior destaque é o Programa Microfone Aberto, da Rádio Primavera, seguido pelo Mais Informação, da Rádio Mais FM.

Assim como o acesso prioritário à programação do rádio, que acontece das $10 \mathrm{~h}$ às $12 \mathrm{~h}$, o principal acesso a conteúdos da TV também tem momento certo do dia para acontecer: a hora do Jornal Nacional (JN). O programa jornalístico da TV Globo foi referenciado por todas as famílias entrevistadas quando questionados sobre quais os conteúdos acessados na mídia televisiva. $\mathrm{O}$ agricultor familiar considera que o JN é a principal ferramenta de mídia capaz de mantê-lo informado a respeito do que acontece no Brasil e no mundo. Por isso, considera importante assisti-lo diariamente ou, pelo menos, sempre que possível.

Contrapondo o acesso ao rádio e à TV, o agricultor familiar não tem hora prioritária para acessar a internet. Por meio do smartphone, a mídia é acessada nos intervalos dos trabalhos domésticos e da lida na roça. De maneira geral, a internet é acessada para usar as redes sociais, como o Facebook e, em especial, o WhatsApp. É nessa última plataforma que ele gasta a maior parte do tempo na internet, falando com familiares e compartilhando vídeos e fotos, especialmente com os que moram longe.

Por sua vez, a mídia impressa não foi mencionada espontaneamente por nenhuma das famílias entrevistadas como uma ferramenta utilizada para se informar. No entanto, o município conta com o Jornal Impacto Xixá, publicação local que trata de informações de toda a região.

No geral, o agricultor familiar não tem o hábito de ler o jornal inteiro, nem de uma vez só. Ele costuma passar os olhos no jornal e ler uma ou outra notícia que o interessa. Ele guarda um exemplar da publicação em casa e, num outro dia, ou noutro momento, retoma a leitura de outro conteúdo que o tenha interessado. $\mathrm{O}$ agricultor familiar dá preferência para conteúdos do próprio município - já que a publicação também retrata assuntos da região -, estabelecendo maior relacionamento com os conteúdos locais, assim como acontece no rádio. Matérias com pouco texto e imagens maiores também são lidas em primeiro lugar. Uma coluna que atribui nota dez e nota zero para diferentes acontecimentos do município também tem especial atenção do agricultor familiar.

O jornal não é considerado pelo agricultor familiar como uma publicação neutra. Ele entende que se trata de uma publicação aliada à atual gestão municipal, o que o faz ler os conteúdos com certa desconfiança. 


\section{Considerações finais}

A observação etnográfica permite compreender o cotidiano da agricultura familiar a partir de sua lógica interna, para além da abordagem midiática e da imagem historicamente forjada. Por meio da imersão, foi possível verificar o valor atribuído à terra como entidade sagrada e a posição da casa como intermediária entre a roça e a rua. $\mathrm{O}$ trabalho e a comercialização de alimentos apresentam-se como elementos determinantes do cotidiano do agricultor familiar. Verificou-se também que os homens assumem o papel de provedores, as mulheres, de gestoras e os jovens, de auxiliares - revelando a lógica da organização da família a partir da produção de alimentos.

No que se refere às condições de vida, o estudo mostra que, apesar de dura, a vida no campo é considerada boa pelo agricultor familiar. A fartura e a própria capacidade de trabalho são elementos fundamentais para o sentimento de apego à roça, mesmo diante das dificuldades de acesso aos direitos básicos no meio rural.

Em se tratando de recepção de mídia, foi possível notar que o agricultor familiar se posiciona diante das notícias abordadas. Durante a discussão que envolve uma escola pública do município, os personagens do estudo evidenciam uma tomada de consciência política relacionada ao acesso a um direito básico: a educação. Quando declara a preferência por programa de entretenimento da TV em detrimento das publicações que envolvem questões políticas e econômicas, o agricultor também denuncia pouco interesse no exercício de direitos políticos. Ao criticar a qualidade dos sinais de internet e de transmissão das emissoras de rádio, ele mostra ainda interesse pelo exercício do direito de acesso à informação. Ao elogiar a participação de médicos e dentistas em programas de rádio, o agricultor também indica que a mídia é uma ferramenta que fornece importantes informações para a manutenção da saúde, outro direito social básico.

A maneira como o agricultor familiar reage aos produtos de mídia mostram que a produção de sentido a partir da recepção de mídia se dá de maneira negociada (HALL, 2003). Isso significa dizer que o receptor investigado pela presente pesquisa não pode ser considerado um "dopado cultural" (LOPES; BORELLI; RESENDE, 2002), revelando certa autonomia das audiências.

Tais indícios são fundamentais para compreender como o acesso à mídia se relaciona com o cotidiano e com o exercício da cidadania no meio rural. A recepção de mídia auxilia na configuração do espaço da cidadania meio ru- 
ral. Mesmo que não se trate de uma cidadania ativa, uma vez que as críticas e desaprovações quanto ao que é veiculado se manifestem apenas no ambiente doméstico, há que se considerar essa relação, que evidencia a postura negociada. Ou seja, a produção de sentido ocorre no processo de mediação entre o que mídia a diz sobre o mundo e a experiência cotidiana do agricultor.

Inserido no cotidiano da família rural sem prejuízos para a atividade produtiva, foi possível notar como o rádio é capaz de estabelecer conexão com a sociedade para além dos limites da porteira. Encontram-se aqui as evidências de que a mídia assume papel fundamental no agendamento dos assuntos que serão discutidos no cotidiano da família. Conectando indivíduos do campo e da cidade em torno de discussões comuns a toda a comunidade, o aprofundamento da recepção dos programas jornalísticos radiofônicos no meio rural pode apontar caminhos sobre os sentidos atribuídos pelo agricultor familiar à informações recebidas.

\section{REFERÊNCIAS}

CANCLINI, Néstor Garcia. Culturas Híbridas: Estratégias para Entrar e Sair da Modernidade. 7. ed. São Paulo: Editora da Universidade de São Paulo, 2015.

COSTA, Fábio Soares da; RODRIGUES, Janete de Páscoa. Contribuições dos cultural studies para o estudo da mídia e da produção de subjetividades nas pesquisas em recepção. Revista FSA, Teresina, v. 11, n. 2, p. 126147, abr./jun. 2014.

ESCOSTEGUY, Ana Carolina. Uma Introdução aos Estudos Culturais. Revista Famecos. v. 5, n. 09. p. 87-97. 1998.

GEERTZ, Clifford. A interpretação das culturas. Rio de Janeiro, LTC, 2015.

HALL, Stuart. Da diáspora: Identidades de medições culturais. Belo Horizonte: UFMG, 2003.

HOGGART, Richard. As Utilizações da Cultura 1. Lisboa: Presença, 1973.

HOGGART, R As Utilizações da Cultura 2. Lisboa: Presença, 1973. 
IBGE. Censo Demográfico 2010. Disponível em: $<$ http://www.censo2010.ibge.gov.br> . Acesso em: 25 de ago. de 2017.

JACKS, Nilda; MENEZES, Daiane; PIEDRAS, Elisa. Meios e audiências: a emergência dos estudos de recepção no Brasil. Porto Alegre: Sulina, 2008.

LOPES, Maria Immacolata Vassalo. Mediação e recepção. Algumas conexões teóricas e metodológicas nos estudos latino-americanos de comunicação. Matrizes, v. 8, n. 1, p. 65-80, jan./jun. 2014a.

LOPES, Maria Immacolata Vassalo. Algumas Reflexões Metodológicas sobre a Recepção Televisiva Transmídia. Revista Geminis, Ed. Especial, p. 13-16. 2014b.

LOPES, Maria Immacolata Vassalo. Estratégias metodológicas para pesquisa de recepção. Revista Brasileira de Comunicação/INTERCOM, v. 16, n. 02, p. 78-86. 1993.

LOPES, Maria Immacolata Vassalo de Lopes; BORELLI, Silvia Helena Simões; RESENDE, Vera da Rocha. Vivendo com a telenovela: mediações, recepção, teleficcionalidade. São Paulo: Summus, 2002.

LOPES, Maria Immacolata Vassalo. et. al. Mediações na recepção de telenovela. Comunicação e Informação, v. 2, n. 2, p. 144-175, jul/dez . 1999

MARCONI, Maria de Andrade; PRESOTTO, Zélia de Andrade. Antropologia: uma introdução. São Paulo: Atlas, 1986.

MARTÍN-BARBERO, Jesús. Dos meios às mediações: comunicação, cultura e hegemonia. 2. ed. Rio de Janeiro: Editora UFRJ, 2001.

SILVERSTON, Roger. Por que estudar a mídia? 4. ed. São Paulo: Loyola, 2014.

THOMPSON, Eduard. P. The Making of the English Working-class. Londres: 1963.

WILLIAMS, Raymond. Culture and Society. Londres, 1958. 
AÇÃO MIDIÁTICA, n.16. Jul./Dez. 2018. Curitiba. PPGCOM-UFPR. ISSN 2238-0701

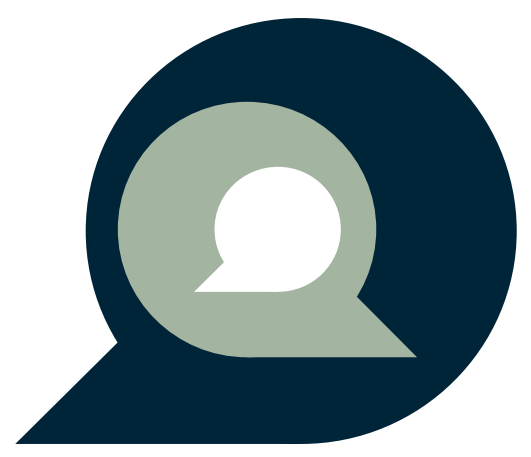

